\title{
目
}

Arch. Min. Sci., Vol. 61 (2016), No 3, p. 461-471

Electronic version (in color) of this paper is available: http://mining.archives.pl

DOI 10.1515/amsc-2016-0033

JOZEF ČECH*

\section{MINING DEPLOYMENT OPTIMIZATION}

\author{
OPTYMALIZACJA ROZMIESZCZENIA WYPOSAŻENIA W KOPALNIACH
}

The deployment problem, researched primarily in the military sector, is emerging in some other industries, mining included. The principal decision is how to deploy some activities in space and time to achieve desired outcome while complying with certain requirements or limits. Requirements and limits are on the side constraints, while minimizing costs or maximizing some benefits are on the side of objectives. A model with application to mining of polymetallic deposit is presented. To obtain quick and immediate decision solutions for a mining engineer with experimental possibilities is the main intention of a computer-based tool. The task is to determine strategic deployment of mining activities on a deposit, meeting planned output from the mine and at the same time complying with limited reserves and haulage capacities. Priorities and benefits can be formulated by the planner.

Keywords: deployment problem, mine planning, optimizing, linear programming, decision support system

Podobnie jak w wojskowości, problem rozmieszczenia wyposażenia pojawia się w wielu gałęziach przemysłu, w tym także górnictwie. Reguły decyzyjne określają jak rozmieścić określone czynności w przestrzeni aby uzyskać pożądane rezultaty w sposób zapewniający zgodność z określonymi wymogami, zapewniający dotrzymanie limitów narzuconych przez ograniczenia, a ponadto by zminimalizować koszty lub maksymalizować korzyści. Przedstawiono model mający zastosowanie do wydobycia złoża metali. Głównym założeniem odpowiedniego narzędzia komputerowego jest dostarczanie inżynierom górnictwa natychmiastowego rozwiązania decyzyjnego z możliwością eksperymentowania. Zadanie polega na określeniu rozmieszczenia czynności górniczych w obrębie złoża, tak by spełnić założenia odnośnie wielkości wydobycia, jednocześnie biorąc pod uwagę ograniczenia mocy przerobowych systemów transportowych, na pierwszym miejscu stawiając zakładane priorytety i korzyści, co jest zadaniem planistów.

Słowa kluczowe: rozmieszczenie wyposażenia, planowanie kopalni, optymalizacja, programowanie liniowe, system wspomagający podejmowanie decyzji

* DEPARTMENT OF MINING, TECHNICAL UNIVERSITY OF KOŠICE, PARK KOMENSKÉHO 19, 04384 KOŠICE, SLOVAK REPUBLIC 


\section{Introduction}

Solution to a mining activity deployment within mine planning process with application to polymetallic ore deposit is presented. The task is to determine strategic placement of mining activities in space of a deposit, meeting planned output from mine and at the same time complying with some limitations of reserves and available capacities, all that with regards to some priorities and benefits as formulated by the planner. In terms of Operations Research, the underlying problem can be solved use of a linear programming model. From the viewpoint of computing terminology, appropriate computer-based tool represent a decision support system capable of interactively and user friendly, to present defined task as well as to provide solution and to facilitate making an optimal decision or to plan quickly and efficiently. Consistently formulated models of many problems are solved by application of methods of linear programming and but also with some commercially available computer programs (including an add-in tool like MS Excel Solver). The paper focuses on application of a system through an interface which effectively supports the tasks of a mining engineer. The use of the system consists of adjusting a general prototype of the mining deployment task template which is offered in a schematic form, approximating mining situation and consequently in entering required values of attributes of generated elements within the scheme. The solution and outcomes are provided by the system within the scheme as well as in the tabulated form, summarizing the tasks.

\section{The problem}

Presented deployment problem within a mining operation on a deposit is generally applicable in ore as well as in coal mining. The task is to find a strategy to deploy mining activities with different capacities available in a particular places of deposit with different amounts and grade of components. The aim is to achieve desirable output from the mine in terms of quantity and quality, respecting the limits of reserves in a deposit and available capacities of activities. The desired outcome is further constrained by some economic concerns such as achieving minimum costs or some benefits and some priorities defined by the planner. The task can then be formulated as follows.

a) Suppose there are a set of reserves within space of deposit available to mine, $j=1,2, \ldots, n R$ where each reserve is described by:

$j-$ identification number,

$c_{j}$ - unit cost of extraction of the reserve,

$\operatorname{Min}_{j}, \operatorname{Max}_{j}$ - minimum requested extraction and maximum possible extraction in given planning situation, resulting from either capacity or residual reserves,

$s_{i, j}$ - consumption of a resource $i$ per unit of extraction, where $i=1,2, \ldots, n S$,

$g_{j, k}$ - percentage grade of component $k$ in reserves, where $k=1,2, \ldots, n G$;

b) extraction can be limited by certain capacity of the resources available - Disp $i$ in a given planning situation;

c) overall extraction of reserves must meet requested plan that is formulated for each of the following items by lower (minimum allowed) limit loLim as well as by upper (maximum allowed) limit upLim for:

- overall amount of extraction $Q$, as mine output,

- overall average grade $G_{k}$ of component $k$ in mine output, for $k=1,2, \ldots, n G$; 
d) the task is to determine intensity of mining activity as an extraction $x_{j}$ from a particular reserve in such a way as:

- to keep it within the minimum and maximum allowed limits of individual reserves,

- not to overstep the capacities of the resources available,

- to fulfil the requested overall plan of extraction in terms of quantity as well as quality,

- to achieve overall minimum $\operatorname{cost} C$;

e) in case of existence of a solution, the outcome is the minimum overall costs of mining activities Cmin and an optimal plan of mining from particular reserves $x$ at a given conditions which presents:

- identification number of reserve $j$,

- recommended optimum extraction $x_{j}$ from given reserve $j$,

otherwise, there is indicated non-existence of solution, stemming from inconsistency of the pertinent task of linear programming.

\section{The model}

The solution of above defined deployment problem is provided by the linear programming methods that enables to settle also large tasks falling into this category (Dantzig, 1998) and (Sultan, 2011).

The formulation of the given task of linear programming can be presented as follows:

$$
C=\sum_{j=1}^{n R} c_{j} x_{j} \rightarrow \min
$$

subject to

$$
\begin{gathered}
x_{j} \geq \operatorname{MinE}_{j} \\
x_{j} \leq \operatorname{MaxE}_{j} \\
\sum_{j=1}^{n R} s_{i, j} x_{j} \leq \operatorname{Disp}_{i} \\
\sum_{j=1}^{n R} x_{j} \geq Q_{\text {loLim }} \\
\sum_{j=1}^{n R}\left(g_{j, k}-G_{k, l o L i m}\right) \cdot x_{j} \geq 0 \\
\sum_{j=1}^{n R} x_{j} \leq Q_{u p L i m} \\
\sum_{j=1}^{n R}\left(G_{k, \text { upLim }}-g_{j, k}\right) \cdot x_{j} \geq 0
\end{gathered}
$$




$$
\begin{gathered}
x_{j} \geq 0 \\
j=1,2, \ldots, n R ; \quad i=1,2, \ldots, n S ; \quad k=1,2, \ldots, n G ;
\end{gathered}
$$

where all the terms have already been defined within the formulation of the problem earlier.

\section{The method}

In terms of mathematical solution of the defined task, there is always a possibility to formulate given task as a dual admissible in the form as follows:

$$
\min \left\{z=\boldsymbol{c}^{\mathrm{T}} \boldsymbol{x}, \mathbf{A} \boldsymbol{x} \geq \boldsymbol{b}, \boldsymbol{x} \geq \mathbf{0}\right\}
$$

where $\boldsymbol{c} \geq \mathbf{0}$

Such task is convenient and effective to solve by the generally known basic dual algorithm of the simplex method (Gass, 2010). Most linear programming tasks in today's practice are solved directly by using computers. Some organisations make use of very large tasks of linear programming (LP) for operations planning. These often need heavy-duty LP solvers, such as CPLEX (from ILOG Inc.) or XPRESS-MP (from Dash, UK). Many operations planning software, such as ILOG's Planner, use LP to plan production and deliveries. LP optimization tools are integrated with many mainstream business systems, such as SAP, Oracle and i2, among others, and also with statistical systems as e.g. SAS (by SAS Institute Inc.).

LP is so widely applicable that it is also included in the Microsoft Excel spreadsheet add-in tools - the Solver. Many LPs can be solved with Excel Solver and many Excel templates, files and add-ins are now available within textbooks, CDs and websites (Lawrence \& Pasternack, 2002; Anderson \& Sweene, 2015). We also can make extensive use of the Excel Solver in our assignment.

Spreadsheets systems have become a powerful tool in management science modelling. Reasons for their popularity includes:

- data are submitted to the modeller in spreadsheets,

- data can be analysed easily using statistical and mathematical tools readily available in the spreadsheets,

- data and information can be easily displayed using graphical charting tools.

Many LP tasks also require the so-called sensitivity analysis, i.e. to investigate how sensitive is the solution on the changes in the coefficients of objective function (unit prices or costs, priorities and the likes) as well as on the changes in the limits within the constraints on the lefthand side of the mathematical model. Since the meaning of our objective function has a special purpose, defined in the text below, this aspect will not be taken into account and presented in this application. However, the Excel Solver enables an output report of the sensitivity analysis in a brilliant form organized in tables.

The above mentioned tools for solution of LP tasks have their application and user basis following the mathematical point of view and formulations without engineering problem-oriented language. The same applies to the Solver. So for practical usage of the model it would be suitable to push the mathematical oriented spreadsheet tools into background and to build a computer system with a mining engineering problem-oriented interface. 


\section{The system}

According to a pioneer in field of decision support systems (DSS), the Alter's classification of DSS (Alter, 1977, 2015), such system falls into the optimization models category which calculate optimal solutions to combinatorial problems convenient particularly for staff analysts at planning and resource allocation. By the more recent Power's classification the matter is so-called modeldriven DSS (Power \& Shardea, 2007). Such systems provide managers with models and analysis capabilities that can be used during decision making process. Usually DSS analyst and the manager needs to understand analytical tools, the model and the problem can be demanding considerable expertise. Therefore regarding the Guimares' factors (Guimaraes et al., 1992) related to the systems success as are implementation characteristics, task characteristics, decision maker characteristics, and other characteristics, these were strongly taken into account. So the main goal of this system building was to provide with an as simple as possible decision aid to the mine planners in order to secure their intentions as well as a comfort level during decision making or planning.

Following from the above, the central idea for computer application was to design an interface of the system as a technical scheme familiar to a mining engineer's view of the task. A session during the solving of the task with the system consist solely of dealing with such a scheme as for its range setting, data entries on the input side and observing the outcomes on the output side. For that, it was convenient to utilize possibilities of a spreadsheet based system as is the MS Excel, involving possibilities of using of dialogues and VBA programming tools (Walkenbach, 2013). Particular sheets within a workbook were possible to specialize according to certain functions within the system and in such way as to build it and to use it step by step in an easy-control and easy-going manner (Wells and Harsharger, 1997).

\subsection{Prototype of the Task}

In the first step of a session scenario a general scheme of the task is offered, asking to enter values of the range parameters which are already defined, i.e. $n R, n S, n G$ (see Fig. 1). All the terms are already known from the previous formulation of the task, provided the user is already familiar with the engineering features of the task.

\subsection{Instance of the Task}

After setting the range of the task, the system is able to inflate the general prototype of the scheme into desirable size. In the second step thus it offers entering particulars of the task in the fashion of an active form. The individual boxes within the scheme of the instance case of the general task are now ready for a click in order to open a dialogue for the entering their parameters exactly according to the definition of the mathematical model. Each of the boxes is thus linked through a VBA subroutine with its respective dialogue. Every dialogue in a clear way is then asking for pertinent parameters for given box exactly according to mathematical formulation of the task (see Fig. 2).

Having finished entering all required input items in their respective boxes, or changing some of them during an analytical study, the task is ready for finding a solution. By pushing the Solution button calculation is running. The solution can then be located in the appropriate boxes in terms of the general scheme in the Prototype of the Task or a message of the task's failure (see 


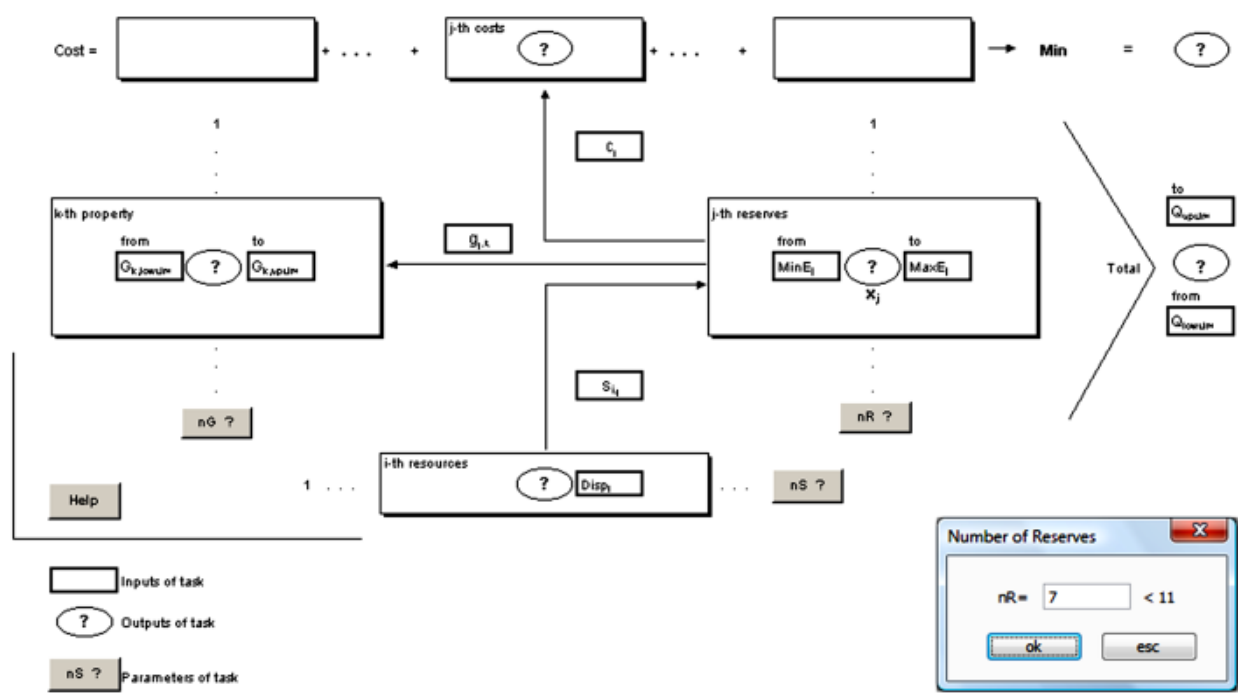

Fig. 1. Prototype of the Task

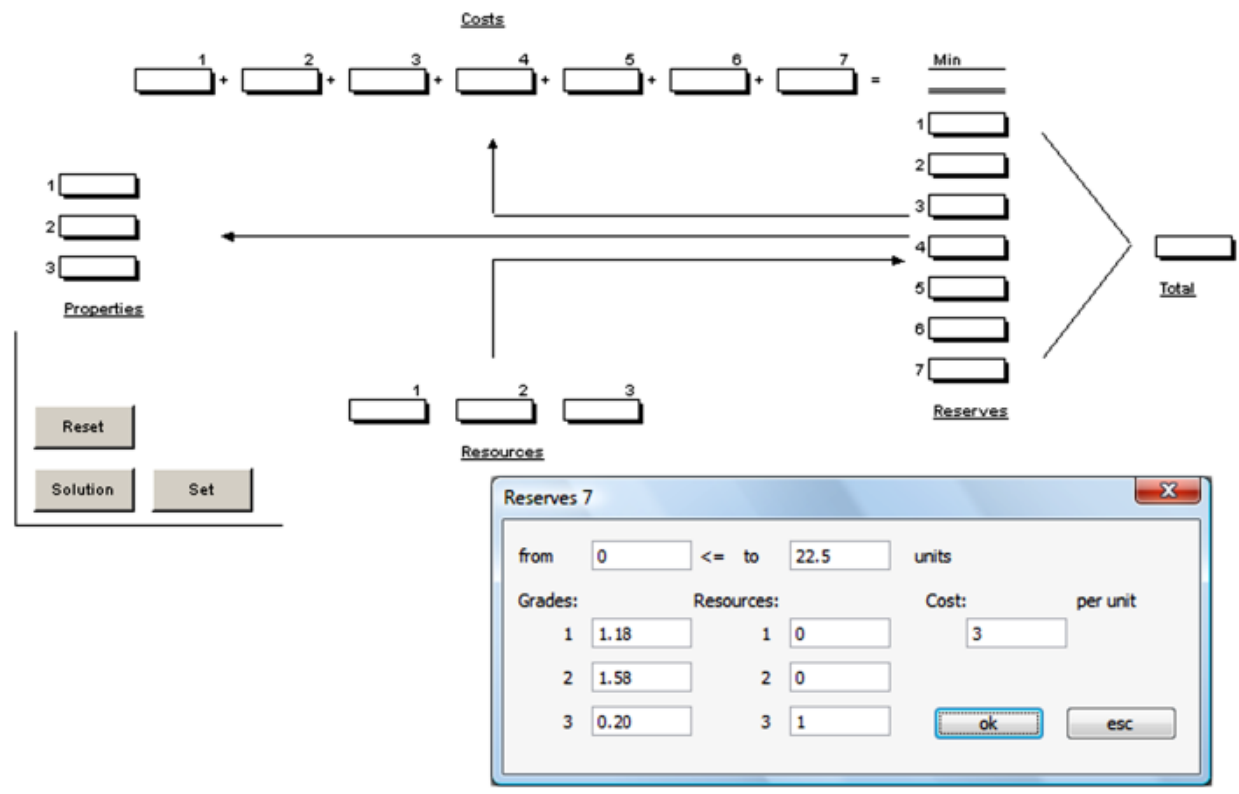

Fig. 2. Instance of the Task

Fig. 3). The Reset button sets the task into a blank form to enable a quick restart of a new task. The Set button sets the task according to the just linked Data of the Task. It enables to restore a task later from an archive by an operative linking of different Data of the Task with the scheme for purpose of additional investigations. 


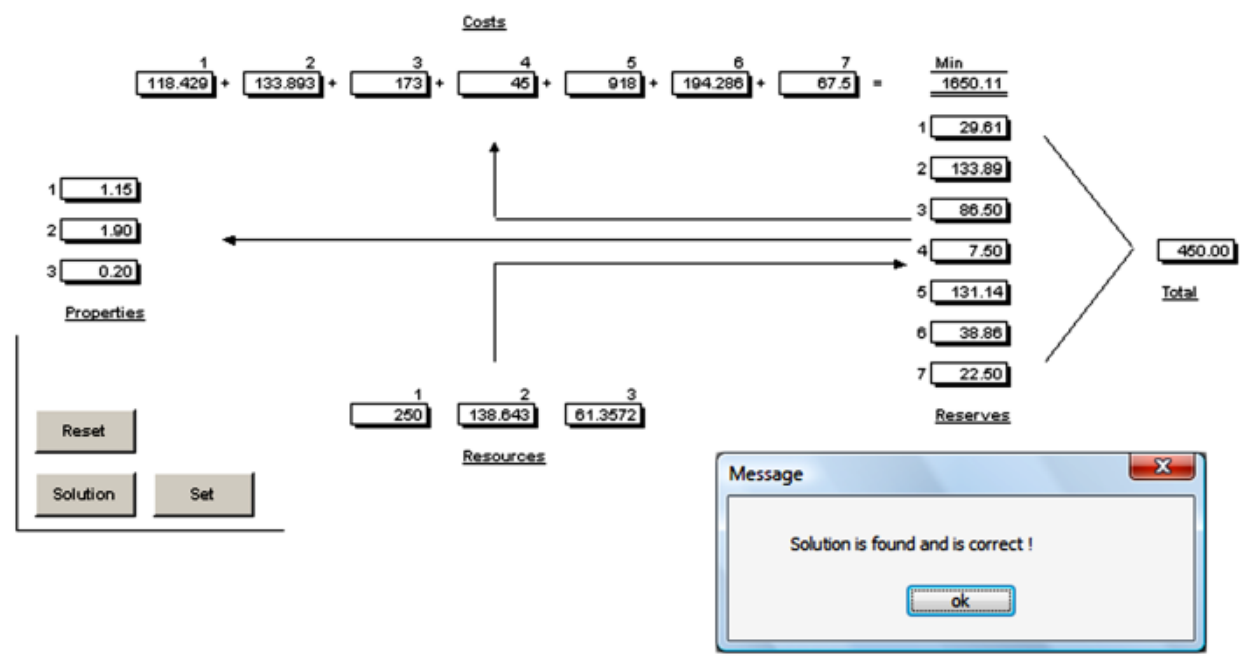

Fig. 3. Solution in Instance of the Task

\subsection{Data of the Task}

It represents the gathered data obtained from the input dialogues and solution of a task and organizes them into tables. It enables a good arrangement of all the data in tabulated form for a complete report of a task and for the purposes of printing, reproduction and archives of tasks for additional overview later (see Fig. 4).

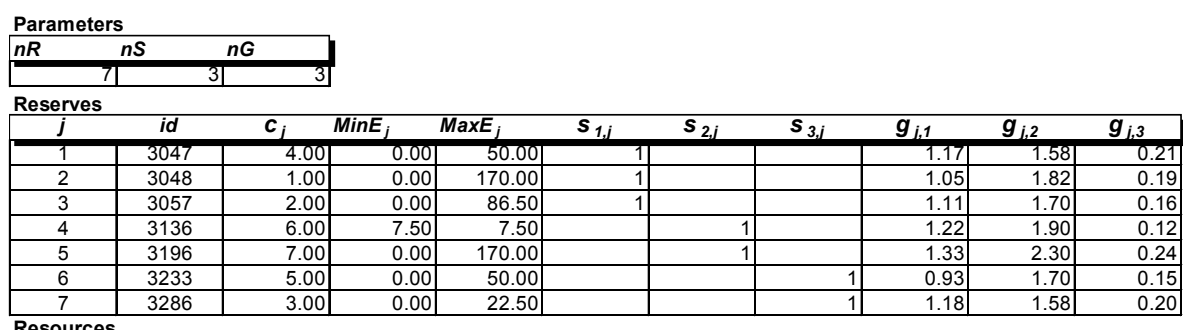

\begin{tabular}{|c|c|c|}
\hline \multicolumn{2}{|c|}{ Resources } & \\
\hline$i$ & $\operatorname{Disp}_{i}$ & \\
\hline 1 & 250.00 & \\
\hline 2 & 170.00 & \\
\hline 3 & 70.00 & \\
\hline \multicolumn{3}{|c|}{ Constraints } \\
\hline index & lowLim & upLim \\
\hline$Q$ & 450.00 & 450.00 \\
\hline $\mathrm{G}_{1}$ & 1.15 & 1.20 \\
\hline $\mathrm{G}_{2}$ & 1.85 & 1.90 \\
\hline $\mathrm{G}_{3}$ & 0.18 & 0.20 \\
\hline \multicolumn{3}{|l|}{ Plan } \\
\hline$j$ & id & $x$ \\
\hline 1 & 3047 & 29.61 \\
\hline 2 & 3048 & 133.89 \\
\hline 3 & 3057 & 86.50 \\
\hline 4 & 3136 & 7.50 \\
\hline 5 & 3196 & 131.14 \\
\hline 6 & 3233 & 38.86 \\
\hline 7 & 3286 & 22.50 \\
\hline
\end{tabular}




\subsection{Others}

Finally, there are some sophisticated tools representing the "brain" of the system, during a session that consists of the following:

- the dialogues encompassing all the VBA dialogues designs that are activated by the clicks on the respective buttons and boxes within the Prototype and Instance of the Task, which are determined for an interactive processing within user sessions. In addition to the dialogues ensuring to enter the parameters and the attributes of the task, there are included also the messages in case of failure of system due to an unqualified treatment as well as a failure of the calculation due to inconsistency of the respective mathematical task.

- the subroutines encompassing:

(a) all the algorithms responsible for the formation and activation of the Instance of the Task itself as well as the control of dialogues assigned to the particular buttons and boxes within it. Some of them are also needed to secure the data transmission between the Data of the Task and the Instance of the Task,

(b) a VBA dual simplex algorithm of solving the given mathematical task, or alternatively, a VBA subroutine running the Excel Solver add-in tool using the data structures provided in the Data of the Task.

\section{The application}

\subsection{Deposit situation}

During mining of a horizon of ore deposit it comes into consideration to extract a set of 7 stopping blocks with the identification numbers: 3047, 3048, 3057, 3136, 3196, 3233, 3286 coding their position in deposit space. Each of the blocks has available certain mineable reserves of polymetallic ore expressed in kilotons ( $\mathrm{kt}$ ), comprising certain percentage of $\mathrm{Pb}, \mathrm{Zn}$ and $\mathrm{Cu}$, for the next mineral processing. A planner has assigned to each of the blocks the maximum possible capacity and the minimum required capacity in the given planning period. Some blocks, with designation of 3048, 3196, has assigned much higher capacities due to good mining conditions as well as higher concentration of the mining equipment. In the contrary, in some blocks, with designation of 3136 or 3286 , there are evidently small left over reserves from the past that have limited their maximum possible contribution into the total extraction. There is also a concern to extract the block of 3136 fully (with only the $7.5 \mathrm{kt}$ of ore left) in order to finish any activity there as soon as possible. From the table of reserves in the Fig. 4 it is clear, that the diversity of the reserves quality as well as the particular possible capacities of the blocks chosen into planning. Obviously, such circumstances complicate the planning under using common sense or purely subjective decision.

\subsection{Costs}

The function of costs as a criterion to determine the optimum plan is in this case substituted by function of priorities. A value of priority, from the interval of $\langle 1,7>$ assigned to each of the blocks taken into deployment consideration, is thus the gauge of planner interest to include 
the particular block into the total planned extraction. Certainly, the interest complies with the inevitability to meet the mathematically formulated constraints as for the capacity limits as well as the total quality and quantity of overall output defined by the total plan mentioned below. In the example, the highest priority is put to the block of 3048 with a concern to engage this block to maximum possible extent into extraction because of high concentration of mining capacity there. In the case of block of 3136, the assignment of the priority of 6 is more or less formal, since the requirement of extraction in full is expressed by the equality of the minimum required and the maximum possible extraction in a given planning period. The assignment of the least priority to the block 3196 implies an intention of the planner in a minimum possible extent to engage this block with the relatively the richest grade of the components in order to preserve it for any future options.

\subsection{Resources}

The using of joint haulage facilities within the sectors of $30,31 \& 32$, the blocks $\underline{30} 47, \underline{30} 48$,

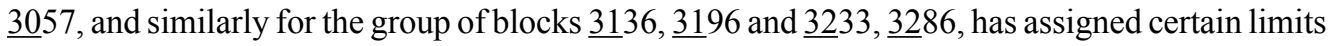
for the maximum possible amounts of ore taken from the respective group to the shaft, and to the mineral processing plant. The limits are $250,170,70 \mathrm{kt}$ for each particular group respectively.

A complete and summarising view of all the entries for the given task is always provided by the Data of the Task, with the separated tables for the parameters of the task, the attributes of reserves, capacities of resources and the required overall plan. A separated table is also provided for the solution of given task (see Fig. 4).

\subsection{Plan}

In this case the task was to plan deployment of mining activities with the extraction of reserves from the particular stopping blocks in such a way as follows:

- in order to fulfil the total plan of extraction from the given horizon and in given period, an amount of 450 kilotons to be mined with the following average grades of components: $\mathrm{Pb}: 1.15$ to $1.20 \%$, $\mathrm{Zn}: 1.85$ to $1.90 \%$, and $\mathrm{Cu}: 0.18$ to $0.20 \%$,

- in order not to go over the capacity possibilities of particular blocks: $3047,3048,3057$, 3136, 3196, 3233, 3286 - in kilotons: 50, 170, 86.50, 7.50, 170, 50, 22.5, and the haulage limits for individual sectors (groups of blocks): 30, 31, 32 - in kilotons: 250, 170, 70, respectively,

- in order to secure full depletion of the block 3136, because of the residual reserve of 7.5 kilotons, and for others there is a possibility to exclude them from extraction in a given period, i.e. no mining activities deployed at a given place,

- engage to maximum extent extraction from the block 3048 through maximum concentration of mining capacity (with assigned priority of 1),

- to a minimum extent (as little as possible) include reserve from the block 3196, in order to preserve of good quality of the ore there (assigned with priority of 7),

- as much as possible to advance activities within the blocks 3057 and 3286, in order to gradually end mining activities in there (assigned priorities of 2 and 3, respectively). 


\subsection{Solution}

As it is pictured in the Instance of the Task (Fig. 2) and in the Data of the Task (Fig. 4), the system has indicated the solution of above defined task and recommends the following optimum plan for the particular blocks: $3047,3048,3057,3136,3196,3233,3286$ to extract: $29.61,133.89$, $86.50,7.50,131.14,38.86,22.50$ kilotons, respectively. The achieved grades of output for $\mathrm{Pb}$ is $1.15 \%, \mathrm{Zn} 1.9 \%$ and $\mathrm{Cu} 0.20 \%$, and the utilizing of resource capacities is for the particular sectors of 30, 31, 32: 250, 138.6, 61.36 kilotons, respectively. Certainly, the value of objective function has got in this case only formal sense and is expressing certain measure of fulfilling the intentions of planner.

From the outcomes, it is possible to state that at the required volume of the plan, at a given grade and the capacity limits of the particular blocks, the contemplated intentions of planner have showed to be viable. For instance, the assumptions to maximise mining the block 3048 (the priority of 1), to speed up the depletion of 3057 and 3286 blocks (with the priorities of 2 and 3 , respectively) and in minimum extent to engage the block 3196 (priority of 7), all that have been proved as possible.

In some unsuccessful trials, during the experimental planning and while searching for other admissible solutions, it is possible, in terms of modelling, to change the planning horizon and to look for better chances to meet the given plan. At the same time, there is possibility of experimental changes of all attributes of the plan, blocks as well as the capacity and resource limits. In such a way a planner can investigate many variants and situations in order to receive good supporting analysis for more objective and rational decision making within the planning procedure.

\section{Conclusion}

The paper describes mathematical model and computer-based interactive tool for solving mining activities deployment problem with an application to mine planning of ore deposits. The aim was to investigate viabilities of some proposals of deployment of mining activities to get a requested output from the mine, respecting reserves available with different grades of components and some capacity constraints, while simultaneously accepting some priorities defined by the planner. The emphasis is on the tool capable to present the problem not, as is usual predominantly in mathematical fashion, but in the engineering oriented scheme, convenient for a mine planner. In such a way, the parameters of task, input data, manipulation and outcomes are technologically oriented. For implementation of the system was MS Excel chosen. It has met all the criteria and requirements to provide all the functionality required for development and use of such application. The success has mainly rested in the combination of possibilities of VBA programming with the Solver add-in tool, enabling solving the many standard tasks of linear programming. The system was tested in a real mining conditions and received very good acceptation from mining professionals. 


\section{References}

Dantzig G.B., 1998. Linear Programming and Extension. Princeton University Press, Princeton.

Gass S.I., 2010. Linear Programming Methods and Application. MacGraw-Hill, New York.

Sultan A., 2011. Linear Programming: An Introduction With Applications (2nd ed.). CreateSpace Independent Publishing Platform.

Lawrence J.A., Pasternack B.A., 2002. Applied Management Science (2nd ed.). Wiley Publishing.

Anderson D.R., Sweene D.J., 2015. An Introduction to Management Science: Quantitative Approaches to Decision Making (14th ed.). South-Western College Pub.

Alter A., 1977. Taxonomy of Decision Support Systems. Sloan Management Review, Fall.

Alter S., 2015. Computer aided decision making in organizations: a decision support systems typology. Leopold Classic Library.

Power D.J., Shardea R., 2007. Model-driven decision support systems: Concepts and research directions. Decision Support Systems. ELSEVIER B.V. 43 (2007) 1044-1061.

Guimaraes T., Igbaria M., Lu M., 1992. The Determinants of DSS Success: An Integrated Model. Decision Sciences 23, No. 2, 1992, 409-430.

Walkenbach J., 2013. Excel 2013 Bible (1st ed). Wiley Publishing, Inc., NJ.

Wells E., Harsharger S., 1997. Microsoft Excel 97 Developers Handbook. Microsoft Press. 